\title{
Secondary school teachers' perspectives on teaching about topics that bridge science and religion
}

Article

Accepted Version

Billingsley, B., Riga, F., Taber, K. S. and Newdick, H. (2014) Secondary school teachers' perspectives on teaching about topics that bridge science and religion. The Curriculum Journal, 25 (3). pp. 372-395. ISSN 0958-5176 doi: https://doi.org/10.1080/09585176.2014.920264 Available at https://centaur.reading.ac.uk/37621/

It is advisable to refer to the publisher's version if you intend to cite from the work. See Guidance on citing.

To link to this article DOI: http://dx.doi.org/10.1080/09585176.2014.920264

Publisher: Taylor \& Francis

All outputs in CentAUR are protected by Intellectual Property Rights law, including copyright law. Copyright and IPR is retained by the creators or other copyright holders. Terms and conditions for use of this material are defined in the End User Agreement.

www.reading.ac.uk/centaur 
Central Archive at the University of Reading

Reading's research outputs online 


\section{Secondary School Teachers' perspectives on teaching about topics that bridge science and religion}

The question of where to locate teaching about the relationships between science and religion has produced a long-running debate. Currently, Science and Religious Education (RE) are statutory subjects in England and are taught in secondary schools by different teachers. This paper reports on an interview study in which 16 teachers gave their perceptions of their roles and responsibilities when teaching topics that bridge science and religion and the extent to which they collaborated with teachers in the other subject area. We found that in this sample, teachers reported very little collaboration between the curriculum areas. Although the science curriculum makes no mention of religion, all the science teachers said that their approaches to such topics were affected by their recognition that some pupils hold religious beliefs. All the RE teachers reported struggling to ensure students know of a range of views about how science and religion relate. The paper concludes with a discussion about implications for curriculum design and teacher training.

Science, religion, teachers, controversy curriculum cross-discipline

\section{Introduction}

This paper looks at the organisation of teaching about what may appear to be a relatively narrow theme, namely the relationships between science and religion. Arguably it is an important case, however, because students' beliefs about how science and religion relate have at least two potential implications. Firstly research which has investigated how young people see the relationships between science and religion has consistently shown over many decades that a majority perceive they are opposed (see for example Bauser \& Poole, 2002; Billingsley, Taber, Riga, \& Newdick, 2013; Brickhouse, Dagher, Letts, \& Shipman, 2000; Dagher \& BouJaoude, 1997; Fulljames, Gibson, \& Francis, 1991; Hanley, 2008). These findings have motivated a concern that a perception that science and religion are mutually exclusive may have a negative 
influence on some students' attitudes to science learning and science based careers (Reiss, 2008). This concern has some support from interview studies and surveys which have shown that some students who have a religious faith hold negative attitudes towards science because they perceive science to be a worldview that opposes their religious beliefs (Fulljames, 1996; Hanley, 2008; Roth \& Alexander, 1997). One of the objectives of science education is to promote the view that the scientific community has a culturally diverse membership and as such, it is important for young people to know that science is not necessarily incompatible with holding a religious faith (Poole, 2008). Secondly an examination of how schools manage themes which bridge science and religion is pressing in the light of recent advances in biomedicine (Reiss, 2012). These advances have prompted widespread calls for teaching that explores the religious, philosophical and ethical issues that the new technology raises and this creates the dilemma of whether to include this teaching in the science curriculum and/or to locate it in another curriculum area (2009; Tytler, 2007; Vasagar, 2012). The question of whether science lessons should address moral, religious and social issues has also been controversial for some time (Reiss, 2008). The stance taken in the 2014 science curriculum in England is that "the social and economic implications of science are important but, generally, they are taught most appropriately within the wider school curriculum" (DoE, 2013, pp. 99-100). By way of a contrast the science curriculum in Australia highlights the cultural context of science and states that children should “explore how science knowledge and applications affect peoples' lives" (Australian Curriculum, Assessment and Reporting Authority, 2011). The existence of these different approaches highlights the importance of finding out how teachers approach cross-discipline themes which are placed inside and across their subjects. 
A curriculum provides teachers with a legitimised canon of knowledge, perspectives, values and interactions between people (Hollins, 2013). When learning about science and religion there are several perspectives that could conceivably be explored, One approach would be to study the different stances that are present in a multicultural society (Broadbent \& Brown, 2012). Another approach would be for students to think about what science and religion mean to them, individually and together (Stolberg \& Teece, 2010). Our interest is particularly in the extent to which schools can support children's developing epistemic insight into the natures of science and religion and a range of views about how they relate. Previous research shows that children are unlikely to be able to understand the reasoning which underpins different views of the relationship without formal or informal teaching (Reich, 1991) and also that the view of the relationship most frequently promoted by the media is that science and religion conflict (Reiss, 2012). The context explored for the current study is England, a country in which science and Religious Education (RE) are typically both taught in secondary schools. It seems reasonable to suppose that science and RE teachers are aware that some of their students may see science and religion as related and possibly competing and that they are also aware of the other curriculum area.

This has led us to pose the following research questions:

- To what extent do teachers plan their teaching in collaboration with teachers who work in the other department?

- How do teachers perceive their roles and responsibilities when teaching topics that both science and religion address?

\section{The relationships between science and religion}


We begin this review of existing research by discussing how the relationships between science and religion are discussed in scholarship. Science and religion are each complex and difficult to define but a useful starting point for educators is that for the most part these disciplines are concerned with distinctive areas of thought (Poole, 2008). Some scholars argue that even where they appear to address the same question, they are interpreting the question in mutually independent ways (Gould, 1999). An example is the question, 'Why is there a universe?' In the so-called 'independence view' it is said that while science is concerned with the physical processes that produced the universe, religion is concerned with the teleological question of whether the universe exists for a purpose (Polkinghorne, 1990). The independence model rests on understanding the natures of science and religion in ways that mean neither encroaches into the other's territory (Barbour, 1988). As science historian, John Brooke notes, not everyone agrees that this is how science and religion should be understood and there are different ways of perceiving the natures of science and religion. In particular, what is dubbed 'creationism' i.e. so called Young Earth Creationism (not to be confused with the traditional religious doctrine of 'Creation'), makes claims about the timeline of the physical universe which conflict with mainstream science. Since there are different views on the natures of science and religion, consequently, there are also different opinions about how they relate (Brooke, 1991).

\section{Children's access to a range of views of the relationship}

The importance of ensuring children have access to a range of views of the relationship between science and religion has been identified by a number of researchers and commentators in education (Astley \& Francis, 2010; Bauser \& Poole, 2002; Billingsley et al., 2013; Francis \& Greer, 2001; Fysh \& Lucas, 1998; Hansson \& 
Redfors, 2007; Reich, 1989; Schneller, 1982). There is a basis to say that young people may struggle to access and understand this range of perspectives. A study by Astley and Francis (2010) highlighted that significant numbers of teenagers believe that religion requires a commitment to Young Earth Creationism and that that science requires a commitment to scientism (the view that science is the only way to provide valid knowledge). The authors argue that teachers need to challenge these presuppositions and that "children need a better understanding of the role and limits of scientific methods", and a better understanding that a Christian belief in creation "is a belief about the ontological dependence of Nature rather than about the details of the universe's origins and development" (Astley \& Francis, 2010, p. 189). This view is supported by Reich (1989) who conducted interviews to explore young people's thinking about the Origins of life and the universe and concluded that without teaching, it is unlikely that students will understand the reasoning behind the independence view of science and religion. He also argued that this helps to explain why a large proportion of people perceive science and religion to be competing. Sharpe (1991) rejected the idea that one view should be put on an intellectual pedestal since there are scholars (i.e. intellectuals) arguing for each of a number of views. Billingsley (2004) suggested that a more evenhanded sign of a good level of knowledge and understanding would be whether someone has the epistemic insight to explain why there is a range of views of how science and religion may relate.

\section{Teaching children in subject compartments}

Our review of the potential difficulties with achieving this objective in secondary school education begins by noticing that each curriculum subject has a specialist teacher and its own pedagogical vision (Mansour, 2009). The question of 
whether it is helpful to have education delivered through discrete subject areas has been explored by Reiss and White (Reiss \& White, 2013, p. 2) who offer an 'aims based' education which begins by asking what young people might need to learn in order to lead a life that is "personally flourishing”. In England and Wales, science and RE are statutory for pupils up to the age of 16 , although parents can choose to withdraw their children from RE lessons. There is a National Curriculum for science. For RE there is a non-statutory national curriculum and the subject is controlled locally through S.A.C.R.E.s (locally-based standing advisory councils for RE) or, in the cases of faith schools, the relevant faith communities. Academies including Free Schools can in some cases develop their own RE syllabus while needing to meet certain requirements. One of the aims of science education is to familiarise children with the methods that scholars use when they construct and validate knowledge. This is readily apparent in the 2014 science curriculum in England and Wales which stipulates that "all pupils should be taught essential aspects of the knowledge, methods, processes and uses of science" (DfE, 2013). An important question in the context of our study is whether science teachers see it as part of their responsibility to help children to understand why some ideas are outside science to test. If teachers in science and RE are working collaboratively, they could link this teaching about science with teaching in RE about the extent to which religious ideas are outside science to test (Poole, 2007). Much of the commentary on science education in recent times has focused on the need to improve children's understanding of that nature of science and in particular to challenge the widespread perception that science is a set of unchanging facts (Taber, 2006).

A focus for commentators on RE for many years has been how to provide a distinctive and purposeful programme for RE with the constraints that is nonconfessional and meets the needs of a multicultural, liberal-democratic society (Barnes, 
2014; Walshe \& Teece, 2013). Although there is an "established" Church of England, the society in England is multicultural. Christianity is the most commonly expressed faith position but within this group there is a wide diversity of beliefs. Barnes (2014) reports that some Christian 'adherents' express scepticism towards beliefs that seem central to Christianity such as belief in a personal God and also that scepticism "is most marked among those of secondary school age.” (Barnes, 2014) p30. Designing a curriculum that recognises a plurality of religious and nonreligious worldviews has not been straightforward. In response to the publication of the 2004 RE Framework critics said that a clearer account was needed of what 'understanding' means in this subject (Walshe \& Teece, 2013). A report by school inspectors highlighted that RE teachers are themselves often unclear about the aims of their subject (OFSTED, 2010). The recently published $2014 \mathrm{RE}$ curriculum includes an objective relating to what children should know about how science and religion relate: "Students develop insight into and understanding of why some people argue that science and religion can be compatible and others argue that they cannot". The intention of this objective is open to different interpretations but it seems to provide an opportunity for children to learn about different perspectives on what science and religion say and about a range of views of the relationship. A similar objective was included in a previous curriculum Framework for RE which recommended that students aged 14 consider different ways to relate scientific and religious explanations of the origins of life and the universe (QCA, 2004). One of the aims of this teaching is for children to explore the argument that science and religion are not necessarily incompatible (Poole, 2005). Part of the intention of our study is to discover whether RE teachers perceive that they are in a position to achieve the aims they have been set. To conclude this section of the review, it appears that a responsibility for helping young people to understand the nature of science is allocated 
to science education, and a responsibility for ensuring that children are in a position to explain that there is a range of views is allocated to religious education.

\section{Collaboration between subjects}

While arguing that the benefits of teacher collaboration appear to be considerable, research shows that across the decades, collaboration between subject specialist teachers in secondary schools is far from the norm (Hart, 2013; Lam, Yim, \& Lam, 2002; Leonard \& Leonard, 2003; W. R. Smith, 2012). When there is collaboration, it is often limited to an exchange of daily anecdotes, or the passing on of a 'trick of the trade' to improve practice (Hargreaves \& Daw, 1990). The literature also attempts to explain why collaboration seldom takes place. The constraint of time pressures has consistently been raised by teachers when they are asked to discuss the barriers to collaboration (Leonard \& Leonard, 2003) but to an extent this is unsurprising as this is the issue teachers typically raise when they are asked about their attitudes to reform (Collinson \& Cook, 2001). Further, Smith (2012) drew together a group of teachers to collaboratively plan and deliver teaching about climate change and provided the group with an administrator to communicate timetable details and sharable resources. Even with this additional support, teachers felt that their working environment was not conducive to collaboration. The conclusion drawn frequently in previous studies is that there are cultural factors that lead teachers to resist collaborative working practices. The environment in schools can be characterised by competition and individualism and each teacher is appointed and made responsible for children's progress in one subject (Leonard \& Leonard, 2003). When teachers are asked to reflect on occasions when collaborative practices have taken take place, the motivation in some 
cases seems to be a concern for children's progress. Leonard and Leonard (2003) describe a teacher who met with her colleagues in the English department to identify common gaps in children's skills in the upper years so that these could be given more attention by those who taught children further down the school. In contrast, Lam et al (2002) report that teachers were reluctant to engage in collaborative practices intended to support teacher development such as peer sharing and observation. If then collaboration is far from the norm, it seems to us that there is a need to ask whether teachers have an understanding of children's educational needs outside the boundary of their specialism and are aware of the interdependencies of their subjects. Since RE teachers have the major responsibility for children's education in this area, we wonder too whether RE teachers feel confident that the two curriculum areas are working sufficiently cohesively to help students progress in their understanding of how science and religion relate.

\section{Cross-discipline teaching within a subject}

A little research has looked at teachers' perspectives on the teaching of topics that bridge science and religion, but mainly in the context of exploring how science teachers approach the teaching of evolution. The American context is a particular focus in such research because in comparison with peer nations, a high proportion of the American public reject evolution in favour of a creationist account (Rosengren, Brem, Evans, \& Sinatra, 2012). In England, research suggests that science teachers report a much lower level of resistance when they teach about evolution (Reiss, 2008). Much thought has been given to the question of whether science teachers should be trying to persuade children to accept evolution. Smith \& Siegel (2004, p. 554) argue that if, 
despite teaching, a student "still disbelieves, we further propose that the appropriate goal is for students to believe that the theory in question affords the best current scientific account of the relevant phenomena based on the available empirical evidence".

Mansour (2009) notes that science teachers' pedagogical beliefs play a significant role in shaping the culture in the classroom. In particular science teachers who believe in a transmission model of learning shape their practice around the transference of knowledge to their students, while those who believe in a constructivist model will take more of an interest in the questions and challenges faced by students. This suggests that a teacher who adopts constructivism is more likely to explore questions about how science and religion relate with students if these are felt to be a barrier to learning. Mansour also advises, however, that not all teachers' beliefs turn into practices and that teachers themselves believe that the principal sources of constraints on their teaching are external pressures and regulations. In contrast, perhaps, McLaughlin (1987) points out, that whatever policies and curriculum documents are in place, the lesson that is actually delivered "depends finally on the individual at the end of the line..." (p. 174).

\section{Children's perceptions of how the subjects relate}

One of the motivations for carrying out this research was that we had recently carried out a preliminary interview study to discover secondary school students' perceptions of how science and religion relate (Billingsley, 2013; Taber, Billingsley, Riga, \& Newdick, 2011). One section of the interview invited students to explain how topics and questions bridging science and religion are managed in their classrooms. 
Several students expressed the view that science and religion had never been discussed together in lessons. Chas (names of the students and their schools have been changed for this report in line with ethical procedures), a student at Ceeside comprehensive school, said, “we've never done like science in religion ... we don't do science and religion, we don't bond them together, we have two different lessons." Some students added that it would not be appropriate to ask a question about the relationship between science and religion in a science lesson. Brenda at Borough School said,

"I think the teacher - we don't really talk about, RS [RE] in science, I don't think the teacher really brings it up, and no-one asks about it, so there's no need for her to bring it up and the same with RS, no-one really asks the science questions, because you'd really more ask your science teacher about that instead of asking your RS teacher."

Alisha, a pupil at Abbey school said that questions in this area rarely came up in class and added that "I think the science teachers do try and avoid them a bit." David at Dalesview Grammar reasoned that a science teacher would see a question about science and religion as outside what the lesson was intended to cover, saying, "We don't ask science teachers questions any more at the moment, because we don't think that they'd answer them. We wouldn't have thought (pause) - oh they won't answer that because it's not on their topic." These comments suggested to us that students have a strong sense that there are boundaries around what can be discussed in each subject and that their perceptions of these subject boundaries are formed at least to some extent around what they think their teacher expects. Further we notice that from a cultural perspective the significance of the teacher as the authority figure in the classroom has been highlighted by a number of researchers (Mansour, 2009, 2013; McLaughlin, 1987; Shanahan \& Nieswandt, 2011).

To summarise this review, the role of the teacher in the classroom is clearly significant not only in determining what is taught but also in shaping the classroom 
culture that guides students as to what types of questions it is or is not appropriate to ask. If as this review suggests, collaboration is far from the norm then in situations such as here, where one curriculum area is somewhat dependent on another, there would surely need to be a means to make particular provision for collaboration and/or ensure that teachers in both areas understand the existence and importance of the interdependent objectives.

\section{Methods}

The study reported here was part of a larger project which involved working with eleven secondary schools to explore pupils' perceptions of science and religion. Eight of the schools also agreed to be part of a parallel study of teachers' views. The eleven schools were in diverse geographical locations England and were mostly identified using an educational directory (Tierney, Sinkie, \& Gregory, 2005). In the cases of two of the schools, colleagues of the research team provided us with a potential school and contact. None of the teachers interviewed were known to the research team. The selection of an RE and a science teacher to take part was made by the project's contact at each school (e.g. head teacher, head of science, or head of RE) with the only criteria being a willingness to take part. Relevant institutional ethical clearance procedures were followed at the universities where the researchers are employed. Interviews were about one hour long and were semi-structured. Participants were told that their names would not be used in our reports of findings and that they could stop the interview at any time. The interviewer (the second author) explained that the purpose of the interviews was to discover teachers' views about how topics relating to science and religion are managed in schools. The interviews were audio-recorded and then transcribed with participants' permission. During the analysis process, the names of participants and their schools were changed. 
The interviews asked teachers about themselves including the subjects they taught, how many years of teaching experience they had, which age groups they taught, their own beliefs about the relationships between science and religion and any personal interest they had in this area. Teachers were then asked how they approach the teaching of topics in the theme, whether pupils asked questions about science and religion and their attitudes towards holding a discussion in class. Teachers were also asked whether they thought their personal beliefs influenced how they approached their teaching and if there were circumstances in which they shared their personal beliefs with their students. Turning to collaboration, we asked teachers about the extent to which the science and RE departments collaborated and what teachers knew about the approach to and content presented in the other (i.e. science or RE) classroom. The final sections of the interview asked teachers about any relevant training they had received in teaching about the relationships between science and religion and for any ideas that had occurred to them during the interview.

\section{Analysis}

In our analysis we considered each of the research questions in turn. The first question is:

- To what extent do teachers plan their teaching in collaboration with teachers who work in the other department?

The analytical method for this question was to study and summarise each teacher's comments about the extent to which staff in the science and RE departments collaborated in his or her school. In the interviews teachers were asked to talk about each of three forms of collaboration (communication, planning, teaching) but in many cases teachers did not address these individually and instead gave an overall picture such as that they knew of no collaboration. The summaries were put into a table with a 
row for each teacher and with teachers paired for each school. From the table we drew inferences about the extent to which collaboration did and did not take place in the participating schools according to this sample of teachers. These inferences are given below with illustrative comments.

The second research question is

- How do teachers perceive their roles and responsibilities when teaching topics that both science and religion address?

To address this question the interview transcripts were first studied individually by all the authors, who then met to discuss the key themes they had noted. In this meeting it was agreed that there were resonances in the concerns and convictions expressed by science teachers and in those expressed by RE teachers respectively but that between these two groups there seemed to be significant differences in the issues that teachers raised. At that point we decided that, for the next round of the analysis, we would keep the science teachers as one group and the RE teachers as a second group. Two of the authors (the first and second) then worked with the transcripts independently for the second round of analysis. In this round we used constant comparative analysis (Strauss \& Corbin, 1998) in the tradition of grounded theory for data analysis guided by our research question. Data were first open coded for each transcript to surface themes pertinent to teachers' accounts of their approaches. We then close coded the data within a set of themes including teachers' beliefs about their aims and their perceptions of factors that influenced their teaching.

Authors one and two then met to compare the results of this process. The themes identified by the authors as affecting teachers' approaches were broadly similar and these were agreed after a process of discussion and inspection of the transcripts. The main difference between the analyses was that while both authors felt that the science 
teachers' approaches seemed to fall into three groups, the criterion was worded differently and this affected the placement of one teacher. One author felt the teachers could be put into three groups on the basis of their attitudes towards holding a discussion in class (opposed, reluctant, positive); the other author grouped the teachers according to the message they felt the science classroom should portray about how science and religion relate (it's nothing to do with science, that religion needs to be respected, that science and religion are not in conflict). The authors consulted another researcher in this field not involved in the project. It was decided to group the teachers according to the first criterion but to discuss both in the presentation of the findings.

The first and second author then worked together to form a narrative describing the teachers' approaches in each of the three groups. The narrative was tested iteratively and repeatedly against the agreed themes and also against the original transcripts to test validity.

\section{Results}

\section{Research Question 1: Collaboration}

The sixteen teachers said they knew of no communication between the RE and Science departments in seven of the eight schools. Mr Beech (RE) said for example, "There is no time at which science teachers and religious studies teachers meet to discuss common ground." Teachers were divided on whether collaboration would be a positive change. Mr Granite argued that science and RE are (and in his opinion should remain) "mutually exclusive" and also that the physical isolation of the science department reinforces the social boundary for staff, "we're over here, we're on our own, science, we never see anyone". In contrast Mrs Acacia (RE) said, "I'm very much in favour of both disciplines walking hand in hand, I think we can learn a lot from each 
other. I think we do need to talk." Several teachers indicated that it would be useful to know more about what was taught in the other curriculum area about topics in this theme but also said there was rarely any interdepartmental communication. Mr Argon (science) said, “we've had no cross-curricular sessions here since I've been here which is (pause) 19 years. [laughs] I think they may be useful, so that at least we know what [the] teacher there is teaching." Ms Jade (science) said: "I've absolutely no idea what they do in RE ... I think it's really hard, because I don't think either side necessarily feel confident." In one school (Hamlet school) some communication had taken place though no formal collaboration.

\section{Research Question 2: Roles and responsibilities Science teachers}

The science teachers' approaches to teaching topics in this theme were divided into three groups:

Group 1: Opposed to discussion: 'nothing to do with science teaching'

Two teachers (Mr Emerald and Mr Granite) saw their role as moving through the science curriculum and presenting the theories, evidence and facts of science in as “objective" (Mr Granite) a manner as possible. Mr Emerald described his school as "a very secular school" with "not many students who have fairly strong religious beliefs". He said science and religion are "completely different things" and felt that Evolution has no relationship to religion, saying "I don't really see how it does relate to religion except that many religious people believe that it does ... I fail to see that it relates to religion". Mr Emerald's strategy was to end or avoid discussion of religion in science classes; if questions do arise, he said,

“you've got to be a little bit careful ... you have to be sensitive ... so you've not got to go in and say, 'Evolution is correct, your beliefs are 
wrong.' But, on the other hand, if they're coming into a science lesson, they have a right to be given a science lesson which involves evidence and unfortunately, there isn't actually any evidence for the Creationist point of view that I've ever come across ... it's the science teacher's responsibility to provide them with evidence".

Mr Granite explained he has to "tip-toe" around sensitive issues (such as

Evolution) for fear of distressing some students, though he feels it unfair that he has to do this. He recalled that in a class taught by another teacher a girl became so upset by a lesson on Evolution that she ran out of the classroom in great distress.

Group 2: Reluctant to hold a discussion: 'try to avoid but show respect'

The second group of teachers - comprising Ms Helium, Ms Jade, Mr Bismuth, Mr Deuterium, Mr Cobalt - were of the view that although their curriculum responsibilities were to teach students science, and although they would prefer not to address questions relating to religion, it was important not to appear to dismiss religion when lessons addressed areas of "overlap" (Ms Jade). Evolution was an example where, in Ms Jade's words, "religion goes over into what I would consider to be sort of science's realm". All of these teachers perceived these areas as controversial and felt that "we can't teach science without talking and reminding ourselves that religion is there and that there are alternative views" (Ms Helium). Ms Helium, a science teacher at a village comprehensive school said her view is widely shared among science teachers who "don't really enjoy discussion" in their classes. She explained why she finds these discussions uncomfortable by pointing out that, when children raise points, they do so in the form of statements about what the Bible says and these come across as challenges rather than questions:

"They say things like, 'but the Bible says ... that this is so'. And it's not really a question, it's more of a statement ... So the questions I would say that are most challenging come - for me, personally-come 
... as statements, 'But how can this be so if this is what they're telling me? ",

Ms Helium was of the view that in practice "sometimes the avoidance tactic is the best one". If a discussion took place her strategy was "not to take part in it as much as possible, I try to let the children bounce off each other ... that they are leading the discussion, and then I'm not forcing my opinions on them".

When asked about teaching topics that relate to religion in science classes, Ms Jade confided "my first reaction, my gut reaction is definitely - that's far too controversial for me to tackle", explaining "I don't feel tremendously well-qualified to talk about it". Ms Jade said that some of her students "have had a big problem with what I've said ... and I don't want there to be a parental comeback or anything like that". Her approach was to be cautious, saying "you've got to tread quite carefully" as some students have "very strong religious views" and these students should not be made to feel "that their values are under attack." She said, "I'm teaching what they need to know for the exam and, I'm teaching what I think is true, but obviously I can understand that there's other views, and, I'm not trying to step on anybody's feet or try to ... convert them to my way of thinking". Ms Jade said that she could empathise with the position for some of her students explaining that, "Personally, I am obviously a scientist, and so I like things where there's empirical evidence to support them but I've also come, come from a fairly religious background, so, I can see that some people do have, have, reservations about science."

Mr Deuterium's views were similar in many ways. A teacher at Dalesview Grammar, he too feels it important to acknowledge to children that people can and do have other beliefs even though, "I suppose as a scientist my approach is based on evidence." Mr Deuterium admits that this theme makes him nervous. He adds, 
"I'm sure I'm not alone in that, I'm not sure it-it's a big scale of things really, and you'll be somewhere on y'know this scale of opinion from being quite open about discussing anything to y'know being, not necessarily um scared - but not-not necessarily as confident to discuss certain issues and feel-y'know, some people probably don't feel they should be discussed".

Mr Deuterium said if there is a discussion it is important "to get the opinions from both sides and ensure that the students understand both sides of the argument". He compared his experiences as a teacher of science with his experiences as an occasional teacher of General Studies. For Mr Deuterium, the tighter boundary set by the science curriculum meant a safe haven for him and his pupils because they could avoid becoming caught up in controversial questions. He added, "it's nice in terms of biology [lessons] cos [you can say] 'look - this is what the exam book says, it's what you have to learn for your exams', and, you can leave it at that".

Mr Cobalt also felt as a science teacher he should not appear to dismiss the significance of religion. He explained that when teaching evolution, "I do touch on it when we do things like the Evolution of the earth. You know, obviously, I've got a slide on the Power Point that says, you know, obviously, the religious beliefs and then I go through the scientific options as well and that's my religious part, I guess, in my science lessons".

Mr Cobalt explained he tries to avoid discussion and gave two reasons for his unease. One is a lack of detailed knowledge about religious approaches (a point echoed by Ms Jade) and the second is that he finds these questions difficult to answer himself, noting that "I don't think you can sort of like marry the two, if I'm being honest with you." In his view, science makes it difficult for pupils to believe in God and this is a position he identifies for himself too. Further, if one belief is challenged "then the whole concept of faith full stop gets questioned, and so I think it does make it more difficult." 
Group 3; Positive about discussion: 'a welcome opportunity'

In the third group, Mr Argon and Mr Bismuth plan time in particular sessions for students to have a discussion about science and religion. Mr Bismuth, like the teachers in the group above, contrasts his own stance with the picture he feels it is important to present to children. He states,

"I personally believe in facts - I need facts to con-prove everything that-that I do, or most things that I do, but I can also accept that there are other people believe, and their faith is something that they don't need proofs for"

Mr Bismuth points out that this theme has become controversial and difficult to handle but says he allocates some time in his lessons for pupils to talk about their views. Mr Bismuth is the only one of the science teachers who described any training in this area, explaining "I went to an inset day" about moral and ethical issues, adding that "everyone in my department knows that I like those kinds of issues." He explains "it seems like everybody is afraid to touch that issue, I believe that it should be touched, especially nowadays in religion - it's such a big part of so many people's lives - it is important to understand how science can fit in with that, even if myself, personally, I'm agnostic," Mr Bismuth states that although there is nothing in his school's science curriculum "to do with religion", he does "end up doing that (science-religion discussion) as an extra-curriculum activity during the lessons" because he recognises that at school "there is no relationship between religious studies and science - no formal relationship between religious studies and science - it is very hard for them to actually see where can those two work together". His aim in sessions is to "create a discussion in which in the end, we accept each other's views - I accept their view because they're entitled to it, and they accept my view because I'm entitled to it"

Mr Argon at Abbey School (a Church school) saw his lessons on origins as a welcome opportunity to challenge the view that science and religion necessarily 
conflict. He explains "when I'm asked questions - I make it clear that as a Christian I have no problem with being a scientist, and in my room there's a cross, and there's also a little sign on the wall which children have to think about - the best (fit) for a Christian is be one". Although Mr Argon, like the majority of science teachers, had received no training in this area, he says he has "always been prepared" to take questions, adding, “I've... I've pretty well worked out in my mind um (pause) the relationship between science and religion, and so I've always felt ready to answer those questions." The view that $\mathrm{Mr}$ Argon presented is that "science is about looking for evidence as to how, the universe began, how the universe runs, how living things are organised, whereas our faith is explaining why." Mr Argon adds that he also points out to pupils, "I'm coming from a particular viewpoint and this is my own explanation, and I accept that other people have their own explanations." When he described the types of questions that students ask, Mr Argon said, "sometimes it's - 'but in RE we've been told that the Earth was created in 7 days' - this is, something I've heard quite commonly ... most of our children are from a church background, and some of those churches have very um fundamentalist viewpoints, others not so fundamentalist, but that is where there are some interesting questions."

We also noted that while Mr Argon said he received many questions about this theme, other teachers (e.g. Mr Cobalt, Mr Granite and Mr Emerald) reported that issues relating science to religion rarely came up in their science classes.

\section{RE Teachers}

The eight RE teachers in this sample were in agreement that the central aim of their teaching was to challenge the idea that the relationships between science and religion is 'either-or'. Ms Elm, a teacher at a Science Specialist school said that the view entrenched in children's minds is 'either-or' and that "students see it as, 'Do you 
want to follow the facts of science, or do you want to follow the faith and belief of religion?"”

Mr Gum explained he wants pupils to also be "aware of the other alternative views that people have." Mr Date made a similar point that "a lot of young people think that if you are religious, you can't believe in things like evolution, and ... the Big Bang”. He maintained that most of his students "have already made up their mind, that if there's a conflict (between science and religion) science is right". Mr Cedar and Ms Juniper admitted it is hard "to get the students to grasp that they (science and religion) aren’t necessarily in opposition”, (Mr Cedar). Ms Juniper explained, “they get extremely passionate about it, and they don't like being told that it is possible to be a religious scientist - some of them are very adamant."

Mr Cedar said that at his school (located in a particularly deprived area) children switch off "the moment you mention the word "religion." To overcome this barrier he reported changing the name of his lesson to Life Skills. Mr Cedar saw his main challenge as trying to persuade students to see that "perhaps there are two sides to it ... it's trying to get the students to grasp that they aren't in opposition - it's not 'you've got to believe one or the other', but actually they can co-exist quite happily".

Many of the RE teachers highlighted that students widely regarded science and religion as competing and that students typically believed that while science gives 'solid' answers supported by evidence, religion gives answers that are unsupported or plain ridiculous. Mr Cedar gave this example of the type of challenge students present,

" "well, who wrote that book (referring to the Bible) - well just anybody can write a book-y'know, we know this happened-science says - we know there's a Big Bang, we know!',"

Mr Cedar felt students' attitudes to religion affect their attitudes to his teaching, explaining, 
"The most frustrating thing for me is that I find science is considered by the students, to be fact, therefore, my subject (RE) cannot be relevant - that's the perception I get, so it's always kind of-you're always on the defensive, you're always being put in the position where you've got to justify why we're delivering what we're delivering, because obviously 'science has proved all these things, so-we know this is wrong!",

Ms Acacia saw the credibility of her subject as losing ground to science, describing her students' position as, “on average [they feel] 'RE's not worth it - it won't give you any answers, whereas science is the way forward for us." Mr Beech suggested that this might be because students simply do not have "the tools" of inquiry necessary, such as "investigation and analysis", to be able to make sense of what they hear about religious and scientific thinking.

The timing of lessons in the school year had been problematic for Ms Hazel, $\mathrm{Mr}$ Gum and Ms Juniper who had found themselves teaching science-related topics before students had covered these topics in their science classes. Ms Juniper said, "we've been begging them (science department) ... so that when we talk about evolution, they know something about it."

The interviews included questions about science subject knowledge. Our analysis revealed that of the eight RE teachers, only Ms Acacia, RE teacher at Abbey School, is comfortable about her level of science subject knowledge, saying that she uses "a lot of scientific arguments and terms within the lessons". Six teachers felt that a weakness in their science knowledge is a significant factor that affected how they respond to questions. Mr Date accepted that, "the Big Bang ... confuses me as a nonscientist" and Ms Hazel also saw subject knowledge as "one of the biggest challenges". It would appear then, that science subject knowledge among RE teachers can be a challenge that affects this theme. 


\section{Discussion}

What seems apparent from this study is that while the literature highlights the importance of ensuring children have access to a range of views of the relationship between science and religion, in practice, this is not straight forward because teaching about science and religion is delivered through two curriculum areas, each with their own culture, pedagogy and contentions, The lack of collaboration between the departments was striking, but perhaps is not surprising. We noted previously that collaboration between teachers in secondary schools is far from the norm, even though research shows it can improve children's education (Ashton-Jones \& Thomas, 1990; Hart, 2013; Lam et al., 2002; Leonard \& Leonard, 2003; Ratcliffe, Harris, \& McWhirter, 2005; 2012, p. 11). What seems likely to us and other researchers is that compartmentalisation is entrenched into teachers' practice in secondary schools by a myriad of factors including teacher training, job titles that ask for specialist teachers, curriculum and examination specifications and timetabling (Hart, 2013; Leonard \& Leonard, 2003). It was evident that the majority of teachers saw the lack of collaboration between the departments as a 'natural' consequence of how schools are. One teacher expressed the view that collaborating might make teachers feel uncomfortable, and two felt strongly that collaboration should not take place. Several teachers said that collaboration would be a positive change.

Turning to the second research question, although the science curriculum makes no reference to religion, all eight science teachers said that an awareness of religion has influenced their approaches to the teaching of particular topics. Mr Argon and Mr Bismuth make time for children to discuss their views about how science and religion relate; Mr Granite and Mr Emerald 'tip-toe' across the controversial territory and the other four teachers 'tread carefully' around these topics and attempt to deter discussion. 
We surmise that these controversial topics are the only times when the majority of these teachers give thought in their teaching to the question of how science and religion relate. This may explain why, when the majority of these teachers talk about their approaches to teaching these topics, their concerns are focused on how to manage the challenges presented by religion(s) that compete with evolution.

Indeed in some interviews the word 'religion' seems to be used synonymously with the notion of a religious view which conflicts with mainstream science. To put this into a wider context, although creationism typically takes centre-stage when science and religion are discussed (Peters \& Hewlett, 2010) in England the view presented by the official state Church (the Church of England) is that science and religion are compatible (Bates, 2006). All the teachers were inclined to think they teach children who hold religious beliefs that are opposed to evolution and faced with this predicament some told pupils that they can opt out of accepting the scientific view and just learn it for the exam. Mr Emerald and Mr Granite, on the other hand, refused to field questions in this area at all, primarily on the grounds that it fell outside the domain of science education (although they also admitted to lacking expertise in this area). What is noticeable about the group of science teachers interviewed is that they seem to be forming individualistic responses to a common dilemma with no 'party line' to draw on. The strategies they employ are individual attempts to balance their responsibilities as curriculum specialists, their pastoral responsibilities, their personal commitments and their relationships with pupils and their parents. In most cases if a discussion took place, teachers resisted critiquing children's views. Mr Argon is in a position to explain the argument underpinning the Independence view but appears not to know whether this is a model that students are expected to know. Perhaps, looking at the curriculum documents, this is not surprising. The value of recognising that there are different ways 
to understand the natures of science and religion and that these have a bearing when considering how they relate is not apparent in the science curriculum, nor is it something (we understood from the teachers) which was discussed during their initial teacher training.

The eight RE teachers interviewed felt that teaching this theme is challenging because of the attitudes that students typically brought to their lessons. The majority of students, according to their teachers, were locked into the view that science and religion conflict and that science is the more formidable force. In our review of the curriculum documents (above) we suggested that there are links between the learning that takes place in the two classrooms in that science lessons teach about the nature of science and RE lessons explore the relationships between science and religion. We found no evidence that science teachers are aware of these links. It is perhaps also significant that while the science teachers interviewed were aware that young people's perceptions of the relationship between science and religion could be a potential barrier to some students' engagement with science, none it seems had considered inviting a scientist who has a religious faith into the classroom to talk with students. Such issues relate a wider debate about the purpose of school science. In this context, the question is whether teachers' responsibilities should include investigating and responding to young people's beliefs about science and scientists.

It is also interesting to notice that for science teachers, the central concern is a recognition that students' religious beliefs may influence their attitudes to the subject and learning of science concepts. By contrast teachers of RE discuss wanting to help students arrive at a greater understanding of how different religious traditions may or may not accommodate scientific ideas. For them, it is a concern when a student who claims to be Church of England considers that teaching about scientific models of 
origins contradicts the account of the creation in Genesis even though the Church of England's teaching suggests the student should not find a conflict if they follow Church teachings. The bridge that seems to be missing between the classrooms is a shared awareness by the teachers of science and RE that learners' beliefs can affect their responses to science teaching and in some cases, these beliefs are based on misconceptions of their own Church's teachings.

Lastly we notice that if we look at the education taking place in both classrooms there seems to be little mention of the value of having explanations that work at different levels and of the possibility that "that scientific knowledge is a subset of religious knowledge" (Reiss, 2010, p. 91). Children are left to focus on points of tension where science and religion are perceived by some people to make contradictory claims. This suggests that children are unlikely to meet the argument that multiple perspectives can sometimes give us a richer narrative than we gain through the lens of one discipline alone.

\section{Recommendations}

This brings us to the recommendations we offer on the basis of this study for teacher practice and education:

The first point relates to the science curriculum and how it is interpreted by science teachers. Based on the picture presented by the RE teachers who participated in this study, a majority of pupils regard science and religion as conflicting worldviews. It seems to us that when a science teacher discusses the evidence which supports the current scientific explanation of the origins of the universe, there is an opportunity to also explain that a scientific explanation is not necessarily incompatible with a religious one. This could be developed into a discussion (whether or not in a science lesson) 
about the types of question that are considered by the range of disciplines that students study. The aim of such a discussion is to encourage students to think about why people hold particular beliefs and which types of claims are open to scientific investigation. We notice that a proportion of young people see science and religion as rival ways of arriving at what they perceive to be competing explanations and as such (according to their RE teachers) are entrenched in the view that there is a choice to make about which to believe. We also notice that there is a wide variation in the approaches taken by the science teachers in this sample. We recommend that the science curriculum needs to have more explicit guidance for teachers about what is expected. This guidance could include highlighting in both curriculum documents that teachers in science and RE are addressing related concepts and that collaboration during the planning of lessons on Origins is likely to improve young people's educational experience. While we recognise that collaboration is a considerable departure from the norm, previous research suggests that teachers are willing to invest the time to implement changes when they can see that these changes will improve students' learning (Leonard and Leonard, 2003). With this said teachers are arguably unlikely to be in a position to consider the potential benefits of collaboration if their students are in the habit of silencing those concerns that they have. This leads us to say that alongside curriculum reform, it would also be useful to look at giving this theme more attention in professional development and teacher training.

Turning then to our recommendations for teacher training, we notice that among the RE teachers interviewed, weak subject knowledge in science was widely felt to be a barrier to effective teaching and this is something that should be addressed; For science teachers, we suggest this study points to a need for a higher level of subject knowledge about the relationships between science and religion and also more pedagogical 
knowledge about what children are expected to know. Many of the teachers said they chose to keep out of class discussions rather than try to influence children's thinking. Ms Hubble said for example that she tries to "let the children bounce off each other" so that she is not "forcing my opinions on them". In such cases, we suggest that teachers are in danger of confusing neutral chair (appropriate for debates about controversial issues) and their role as mentors of children's developing understanding of the nature of knowledge and the issues that affect society. Our recommendation is that in such discussions teachers should make use of the opportunity to give students an insight into the natures of science and religion, how the media present the relationships between science and religion and how they are presented in scholarship.

\section{Recommendations for further research}

This study points to a high level of resistance among science teachers to providing teaching and/or discussions about the relationships between science and religion. Given that there is also a high level of resistance to collaboration in schools, it seems to us that there may be other ways that teachers could help students to progress in their interdisciplinary epistemic insight - such as by exploring questions that bridge science and history. It would be useful, we propose to explore the impact of such lessons on students' reasoning about the nature of science. Part of the research would look at whether students can draw on what they have learnt about the relationships between science and history when they are asked to discuss the relationships between science and religion. The selection of historical examples that might be used to offer a context for interdisciplinary teaching need to be selected carefully "to allow for differences in experiences and in what particular localities have to offer, so that students' interests and questions are used as starting points" as Harlen (2010, p. 11) expresses it. 
Ashton-Jones, E., \& Thomas, D. K. (1990). Composition, collaboration, and women's ways of knowing: A conversation with Mary Belen. Journal of Advanced Composition, 10(2), 275-292.

Astley, J., \& Francis, L. J. (2010). Promoting positive attitudes towards science and religion among sixth-form pupils: dealing with scientism and creationism. British Journal of Religious Education, 32(3), 189-200.

Barbour, I. (1988). Ways of relating science and theology. In R. J. Russell, W. R. Stoeger \& G. V. Coyne (Eds.), Physics, Philosophy and Theology: A Common Quest for Understanding (pp. 21-42). Vatican City State: Vatican Observatory.

Barnes, L. P. (2014). Education, Religion and Diversity: Developing a New Model of Religious Education: Routledge.

Bates, S. (2006). Archbishop: stop teaching creationism. The Guardian, (Tuesday 21 March). http://www.guardian.co.uk/uk/2006/mar/21/religion.topstories3

Bauser, J., \& Poole, M. (2002). Science education and religious education: possible links? School science review, 85(311), 117-124.

Billingsley, B. (2004). Ways of Approaching the Apparent Contradictions between Science and Religion. (PhD), University of Tasmania.

Billingsley, B. (2013). Students' Perceptions of Apparent Contradictions Between Science and Religion: Creation Is Only the Beginning Science Education for Diversity (pp. 329-338): Springer.

Billingsley, B., Taber, K. S., Riga, F., \& Newdick, H. (2013). Secondary School Students' Epistemic Insight into the Relationships Between Science and Religion; A Preliminary Enquiry. Research in Science Education, 43(4), 17151732. doi: 10.1007/s11165-012-9317-y

Brickhouse, N. W., Dagher, Z. R., Letts, W. J., \& Shipman, H. L. (2000). Diversity of Students' Views about Evidence, Theory, and the Interface between Science and Religion in an Astronomy Course. Journal of Research in Science Teaching, 37(4), 340-362.

Broadbent, L., \& Brown, A. (2012). Issues in religious education: Routledge.

Brooke, J. (1991). Science and Religion: Some Historical Perspectives. Cambridge: Cambridge University Press.

Collinson, V., \& Cook, T. F. (2001). â€œI donâ€TMt have enough timeâ€• Teachersâ€ $€^{\mathrm{TM}}$ interpretations of time as a key to learning and school change. Journal of educational administration, 39(3), 266-281.

Dagher, Z. R., \& BouJaoude, S. (1997). Scientific views and religious beliefs of college students: The case of biological evolution. Journal of Research in Science Teaching, 34 (5), 429-445.

DfE. (2013). National curriculum in England: science programmes of study (for Key Stage 3). London: Department for Education Retrieved from https://www.gov.uk/government/collections/national-curriculum.

DoE. (2013). National Curriuclum for Science for 2014. London: Department of Education.

Francis, L., \& Greer, J. (2001). Shaping adolescents' attitudes towards science and religion in Northern Ireland: the role of scientism, creationism and denominational schools. Research in Science and Technology Education, 19, 3953. 
Fulljames, P. (1996). Science, creation and Christianity: a further look. In L. Francis, W. Kay \& W. Campbell (Eds.), Research in Religious Education (pp. 257-266). Leominster: Gracewing.

Fulljames, P., Gibson, H., \& Francis, L. (1991). Creationism, Scientism, Christianity and Science: a study in adolescent attitudes. British Educational Research Journal, 17(2), 171 - 190.

Fysh, R., \& Lucas, K. B. (1998). Science and religion: acknowledging student beliefs. Australian Science Teachers Journal, 44(2), 60-68.

Gould, S. J. (1999). Rocks of Ages: Science and Religion in the Fullness of Life. New York: Ballantine Books.

Hanley, P. (2008). Controversy in school?: Origin of life and the science/religion overlap. Paper presented at the British Educational Research Association Annual Conference, Heriot-Watt University, Edinburgh, September, HeriotWatt University, Edinburgh.

Hansson, L., \& Redfors, A. (2007). Physics and the Possibility of a Religious View of the Universe: Swedish Upper Secondary Students' Views Science \& Education, 16(3-5), 461-478. doi: 10.1007/s11191-006-9036-8

Harlen, W. (2010). Principles and big ideas of science education. Hartfield: the Association for Science Education.

Hart, R. T. (2013). How feasible is interdisciplinary teacher collaboration in high schools? an in-depth comparison of Kyberpass at two school sites.

Hollins, E. R. (2013). Transforming curriculum for a culturally diverse society: Routledge.

Lam, S.-f., Yim, P.-s., \& Lam, T. W.-h. (2002). Transforming school culture: can true collaboration be initiated? Educational Research, 44(2), 181-195.

Leonard, L., \& Leonard, P. (2003). The continuing trouble with collaboration: Teachers talk. Current Issues in Education, 6(1), 1-14.

Mansour, N. (2009). Science teachers' beliefs and practices: Issues, implications and research agenda. International Journal of Environmental \& Science Education, $4(1), 25-48$.

Mansour, N. (2013). Modelling the sociocultural contexts of science education: The Teachers' perspective. Research in Science Education, 43(1), 347-369.

McLaughlin, M. W. (1987). Learning from experience: lessons from policy implementation. Educational Evaluation and Policy Analysis(9), 171-178.

OFSTED. (2010). Transforming Religious Education. Religious Education in Schools, 2006-09.

Peters, T., \& Hewlett, M. (2010). Can You Believe in God and Evolution?: A Guide for the Perplexed: Abingdon Press.

Polkinghorne, J. (1990). God's Action in the World. Paper presented at the J.K.Russell Fellowship Lecture on April 6, 1990, at the Pacific School of Religion Chapel in Berkeley, .

Poole, M. (2005). Science and Education. In S. C. (Ed.), God, Humanity and the Cosmos (pp. 303-320). London: Continuum.

Poole, M. (2007). A User's Guide to Science and Belief: Lion Books.

Poole, M. (2008). Creationism, intelligent design and science education. School science review, 90(330), 123-129.

QCA. (2004). Religious Education: The non-statutory national framework. London: DfES Retrieved from http://www.mmiweb.org.uk/publications/re/NSNF.pdf. 
Ratcliffe, M. (2009). The place of socio-scientific issues in citizenship education. In A. Ross (Ed.), Human Rights and Citizenship Education. (pp. 12 - 16). London: CiCe.

Ratcliffe, M., Harris, R., \& McWhirter, J. (2005). Cross-curricular collaboration in teaching social aspects of genetics Research and the Quality of Science Education (pp. 77-88): Springer.

Reich, H. (1989). Between religion and science: Complementarity in the religious thinking of young people. British Journal of Religious Education, 11(2), 62-69.

Reich, H. (1991). The role of complementarity reasoning in religious development. New Directions for Child and Adolescent Development, 1991(52), 77-89. doi: 10.1002/cd.23219915207

Reiss, M. J. (2008). Should science educators deal with the science/religion issue? Studies in Science Education, 44(2), 157-186 doi: 10.1080/03057260802264214

Reiss, M. J. (2012). What should be the role of religion in science education and bioethics? Sacred Science? (pp. 127-139): Springer.

Reiss, M. J., \& White, J. (2013). An aims-based curriculum: The significance of human flourishing for schools: IOE Press.

Rosengren, K. S., Brem, S. K., Evans, E. M., \& Sinatra, G. M. (2012). Evolution challenges: integrating research and practice in teaching and learning about evolution: Oxford University Press.

Roth, W. M., \& Alexander, T. (1997). The interaction of students' scientific and religious discourses: two case studies. International Journal of Science Education, 19(2), 125-146.

Schneller, R. (1982). The science-religion problem: Attitudes of religious Israeli youth. Youth and Society, 13 (3), 251-282.

Shanahan, M.-C., \& Nieswandt, M. (2011). Science student role: Evidence of social structural norms specific to school science. Journal of Research in Science Teaching, 48(4), 367-395. doi: 10.1002/tea.20406

Sharpe, K. (1991). Relating science and theology with complementarity: A caution. Zygon: Journal of Religion and Science, 25 (4), 365-385.

Smith, M. U., \& Siegel, H. (2004). Knowing, believing, and understanding: What goals for science education? Science \& Education, 13(6), 553-582.

Smith, W. R. (2012). Culture of Collaboration. School Administrator, 69(1), 14-20.

Stolberg, T., \& Teece, G. (2010). Teaching religion and science: Effective pedagogy and practical approaches for RE teachers: Routledge.

Strauss, A., \& Corbin, J. (1998). Basics of Qualitative Research: Techniques and Procedures for Developing Grounded Theory (2nd ed.). Thousand Oaks, California: Sage.

Taber, K. S. (2006). Exploring pupils' understanding of key 'nature of science' terms though research as part of initial teacher education. School science review, 87(321), 51-61.

Taber, K. S., Billingsley, B., Riga, F., \& Newdick, H. (2011). To what extent do pupils perceive science to be inconsistent with religious faith? An exploratory survey of 13-14 year-old English pupils. Science Education International, 22(2), 99118.

Tierney, J., Sinkie, E., \& Gregory, J. (Eds.). (2005). Education Yearbook 2005/2206. Harlow, England: Pearson Education.

Tytler, R. (2007). Re-imagining science education: Engaging students in science for Australia's future Australian Education Review: Australian Council for Educational Research. 
Vasagar, J. (2012, Tuesday 12 June 2012). Michael Gove's curriculum attacked by expert who advised him, The Guardian. Retrieved from

http://www.guardian.co.uk/education/2012/jun/12/michael-gove-curriculumattacked-adviser

Walshe, K., \& Teece, G. (2013). Understanding 'religious understanding' n religious education. British Journal of Religious Education, 35(3), 313-325. 